\title{
北海道中標津町における乳牛の衛生管理に 関する実態調查
}

\section{II. 乳牛の多発疾病についての解析}

\author{
酒井健夫*1. 武石昌敬 ${ }^{* 1} \cdot$ 長尾壮七*1
}

鈴木成夫 ${ }^{* 2} \cdot$ 駒井義一 ${ }^{* 2}$

著者らは, 北海道東部地域の乳牛の飼育環境の改 善を図る目的で，数年にわたり策態調查を行ってき た。今回は, 问地域の衛生管理状況を知る手懸の- つとして乳牛の多発疾病について解析を試みた。

\section{資料及び方法}

調査地域は北海道東部の標津郡中標津町で, 当地 域を河川流域などの地形的要因により6地区（A F）に紼分した。症例は，中標津町農業協同組合家 苗㟝療所で診断治療したもので，家畜共済事故病類 別表 ${ }^{3)}$ に準じて16病類に分類した。

なお発病頭数は受診頭数であり，発病率は $\chi^{2}$ 検定 を用いて比較した。

\section{成絙及び考察}

調査地域における共済加入酪農家戸数は，A地区 49戸， B 地区55戸，C 地区37戸，D地区58戸， E 地 区69戸及び F 地区50户，合計 318 戸であり，酪農家 1 戸当りの平均加入乳牛頭数は 46.3 頭であった。

調査全地域の延べ発病頭数は 10,056 頭/年で, 発 病率は $5.7 \%$ であった。年間の発病症例のうち, 乳 房疾患 $(28.8 \%$ : 病類別発病頭数 /全発病頭数) 及 び泌尿生殖器病（25.4\%）は半数以上で, ついで連 動器病 $(16.5 \%)$, 妊娠·分婏·産後の疾患 $(14.5 \%)$ 及び消化器病 (6.2\%)の発生頻度が高かった（表 1 )。 全病類のうち乳房疾患及び泌尿生殖器病の占める比 率は, 全国の場合でも高く ${ }^{4}$ ，また濃厚飼料の多給と 年間を通じて舎内飼育を行っている場合でも多発し ているので、゙,これらの疾病はいかなる飼育形態でも 多発する，乳牛に共通の現象と考えられる。

調查地域を河川流域及び幹線道路によって細分し た 6 地区の年間発病率 [発病頭数 / (飼育頭数 $\times 12)]$

*1 日本大学農獣医学部

*2 中標津農業協同組合
を比較すると，A地区では6.6\%，B地区では6.5\% であり，ついでC (5.9\%)，D (5.6\%) 地区であっ た。E (4.9\%) 及びF (4.9\%) 地区の発病率は低 かった（表 2$)$ 。このことは，土壤，牧草等の直接的 要因あるいは酪農家の生活・経済水準及び意識など の間接的要因にもとづくものか否かは，今後の調査 で明らかにしたいが, 地域的特性が存在することを 認めた。

調查全地域での月別発病率（月別発病頭数/飼育 頭数)は，10月及び11，12，1，2 月の冬季では3.9 ～ $4.9 \%$ と低く，4月及び $6 ， 7 ， 8$ 月の夏季では 6.3〜7.4\%と高かった（表 3 )。このように当地域で は，疾病は夏に多発する夏季集中型を示した。した がって, この地域では, 乳牛を 5 月〜 10月にかけて 放牧するので, 放牧との関連が考えられる。また嶋 は盛夏の乳牛の生産性には 4 5 日の貯蔵粗飼料の 品質劣化が関与しており, 飼料給与計画や管理の改 善の必要性を指摘しているので，これらが夏季の疾 病多発に対する一要因とも推論できる。

主な病類の発病率の月別比較では, 泌尿生殖器病 及び乳房疾患の発生率（19.5 32.1\%，25.7～33.0 \%) は年間を通じて高く，季節的変動は認められな かった。消化器病の発生率は, 放牧期間中の $7 \sim 9$ 月 $(3.8 \sim 4.9 \%)$ が他の月 $(5.8 \sim 9.0 \%)$ に比べて 明らかに低かったが， 5 月の発生頻度が高かった。 これは, この時期では, 貯蔵粗飼料の品質低下にく わ之，放牧初期の放牧馿致の不徹底，特に青草に对 する順化の不足と，それに伴なうルーメン発酵異常 と下痢及び急激な運動量の増加などに起因して発病 率が高くなった2) ものと推定された。したがって今 後は, 放牧馴致に必要な予備飼育を十分考虑する必 要がある。

連動器病の発病率は放牧期間の 6 ～月に多発し (22.0〜26.6\%)，夏季集中型を示したので，放牧時 
酒井・武石・長尾・鈴木・駒井：北海道中標津町における乳牛の衛生管理に関する実態調查 17

表 1 調查地域における共済加入酪農家戸数, 乳牛頭数および病名別年間発病頭数

\begin{tabular}{|c|c|c|c|c|c|c|c|}
\hline 区 & A 地区 & B 地区 & C地区 & D地区 & E地区 & $\mathrm{F}$ 地区 & 全調査地域 \\
\hline 酪農家戸数 ：総数 & $4 \mathrm{C}$ & 55 & 37 & 58 & 69 & 50 & 318 \\
\hline 加入乳牛頭数: 総数 & 2353 & 2736 & 1703 & 2369 & 3334 & 2244 & 14739 \\
\hline $\begin{aligned}: \text { 一戸当りの平均 } & \\
& (\min \sim \max )\end{aligned}$ & $\begin{array}{c}48.0 \\
(3 \sim 175)\end{array}$ & $\begin{array}{r}49.7 \\
(8 \sim 87)\end{array}$ & $\begin{array}{r}46.0 \\
(5 \sim 95)\end{array}$ & $\begin{array}{r}40.8 \\
(5 \sim 74)\end{array}$ & $\begin{array}{c}48.3 \\
(4 \sim 107)\end{array}$ & $\begin{array}{r}44.9 \\
(4 \sim 88)\end{array}$ & $\begin{array}{r}46.3 \\
(3 \sim 175)\end{array}$ \\
\hline 発生総回数 & 1874 & 2118 & 1206 & 1581 & 1948 & 1329 & 10056 \\
\hline 病類別発生頭数 & & & & & & & \\
\hline 伝染病 & 38 & 27 & 7 & 10 & 22 & 12 & 116 \\
\hline 寄生虫病 & 1 & 0 & 0 & 0 & 0 & 0 & 1 \\
\hline 血液病 - 代謝疾患 & 35 & 44 & 30 & 17 & 40 & 13 & 179 \\
\hline 消化器病 & 108 & 102 & 80 & 97 & 135 & 104 & 626 \\
\hline 呼吸器病 & 30 & 42 & 33 & 36 & 38 & 15 & 194 \\
\hline 循環器病 & 9 & 5 & 4 & 5 & 10 & 3 & 36 \\
\hline 姡娠 - 分べん・産後の疾患 & 280 & 287 & 153 & 225 & 308 & 202 & 1455 \\
\hline 泌尿生殖器病 & 560 & 532 & 226 & 466 & 455 & 318 & 2557 \\
\hline 乳房の疾患 & 522 & 623 & 366 & 459 & 562 & 359 & 2891 \\
\hline 連動器病 & 219 & 385 & 268 & 232 & 294 & 263 & 1661 \\
\hline 神経系病 & 7 & 10 & 6 & 7 & 11 & 5 & 46 \\
\hline 眼病 & 8 & 6 & 0 & 2 & 2 & 0 & 18 \\
\hline 皮䖉病 & 15 & 10 & 4 & 6 & 4 & 2 & 41 \\
\hline 外偟不虑 & 40 & 41 & 26 & 18 & 60 & 30 & 215 \\
\hline 中毒 & 2 & 3 & 3 & 0 & 5 & 1 & 14 \\
\hline その他 & 0 & 1 & 0 & 1 & 2 & 2 & 6 \\
\hline
\end{tabular}

表 2 全調査地域における発病率の地区別比較

\begin{tabular}{lccccccc}
\hline 地 区 & A 地区 & B 地区 & C 地区 & D 地区 & E 地区 & F 地区 & 全地域 \\
\hline 飼育頭数 (頭) & 2353 & 2736 & 1703 & 2369 & 3334 & 2244 & 14739 \\
発病頭数 (頭) & 1874 & 2118 & 1206 & 1581 & 1948 & 1329 & 10056 \\
発病率 $(\%)^{\mathrm{a})}$ & 6.6 & 6.5 & 5.9 & 5.6 & 4.9 & 4.9 & 5.7 \\
\hline
\end{tabular}

a) : $\frac{\text { 地区(域) 発病頭数 }}{\text { 地 }} \times 100$

$\chi^{2}$ 検定結果： A

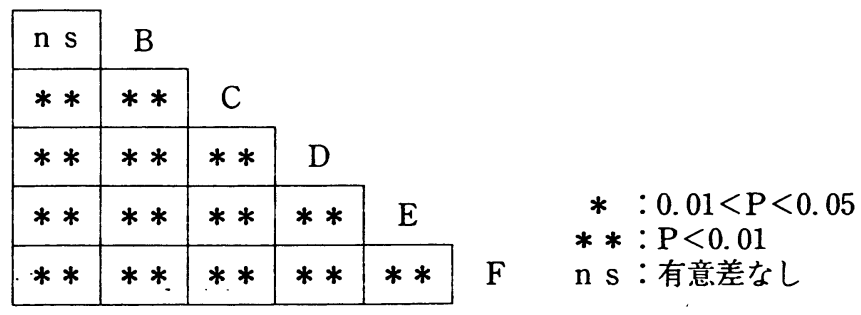


表 3 全調查地域における発病率の月別比較

\begin{tabular}{lrrrrrrrrrrrr}
\hline 月 & 1月 & 2 月 & 3 月 & 4 月 & 5 月 & 6 月 & 7 月 & 8 月 & 9 月 & 10月 & 11 月 & 12 月 \\
\hline 発病頭数 (頭) & 580 & 701 & 864 & 1000 & 857 & 1090 & 1042 & 928 & 889 & 727 & 656 & 722 \\
発病率 $(\%)^{\mathrm{a})}$ & 3.9 & 4.8 & 5.9 & 6.8 & 5.8 & 7.4 & 7.1 & 6.3 & 6.0 & 4.9 & 4.5 & 4.9 \\
\hline
\end{tabular}

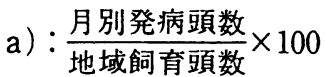

$\chi^{2}$ 検定結果： 1

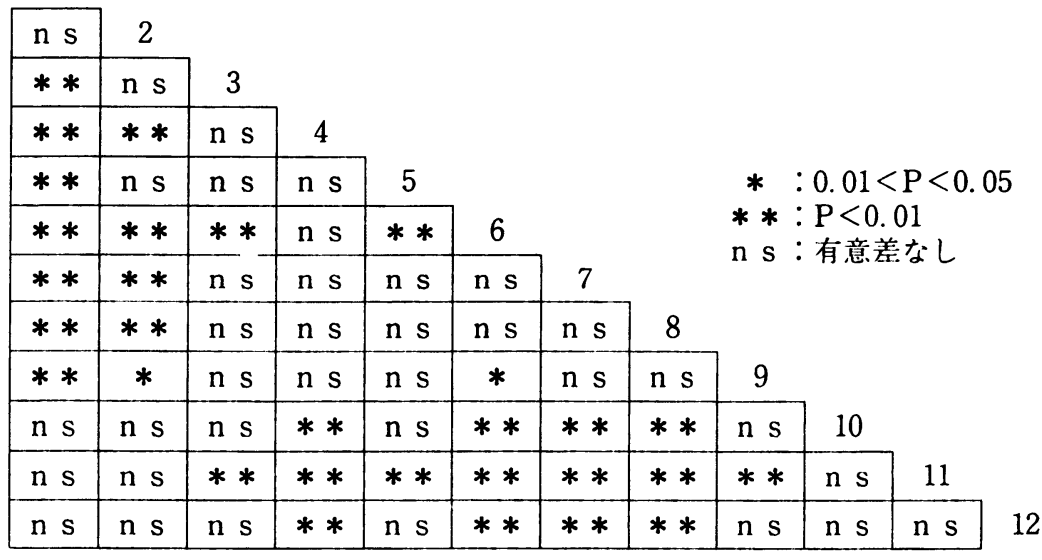

の飼養管理・放牧衛生に,より一層の注意を払う必 要がある。

以上乳牛の疾病発生状況には, 地域的, 季節的影 響が存在するものと推定され、これらの要因を改善 することにより生産性はさらに向上されるものと判 断された。

当原稿は獣医統計利用研究会第11回シンポジウム の発表用資料であり，東京獣医学畜産学雑誌，第30 巻第 1 号に揭載した原著「北海道中標津町における 乳牛の発病状況に関する調查」より作成した。

\section{引用交献}

$1 ）$ 加藤寿次ら：獣医畜産新報。 $666,19-24,1977$.

2 ）小泉俊二ら：苗産技術．230，12-18，1974.

3 ) 農林水産省経済局：家畜共済の事務取扱処理の 要領. 103-112, 1981.

4 ）農林水産省畜産局：昭和54年家畜衛生統計. 106-107, 1979.

5 ）嶋功：酪総研調査研究報告. 5, 93-96, 1979. 